\title{
Evaluation of Antibacterial and Antibiofilm Activity of New Antimicrobials as an Urgent Need to Counteract Stubborn Multidrug-resistant Bacteria
}

\author{
Ahmed R. Sofy ${ }^{1 *}$ (D), Akram A. Aboseidah², El-Shahat El-Morsi², \\ Heba A. Azmy² and Ahmed A. Hmed ${ }^{1}$ \\ ${ }^{1}$ Botany and Microbiology Department, Faculty of Science, Al-Azhar University, 11884 Nasr City, Cairo, Egypt. \\ ${ }^{2}$ Botany and Microbiology Department, Faculty of Science, Suez University, Suez, Egypt.
}

\begin{abstract}
The biggest problem in the world today is antimicrobial resistance, which undermines human health and increases morbidity and mortality associated with life-threatening serious diseases. Scientists from different fields are therefore examining plants for their antimicrobial use in the face of multidrug-resistant bacteria with a new eye. So, the aim of this research to find a new antibacterial from five aqueous extracts of Nigella sativa, Ziziphus spina-christi, Rosmarinus officinalis, Origanum majorana, and Allium sativum medicinal plants tested against the most multidrug-resistant bacterial isolates from clinical specimens which were Klebsiella pneumoniae (Gram-negative), Escherichia coli (Gram-negative), Pseudomonas aeruginosa (Gram-negative), Staphylococcus aureus (Gram-positive) and Methicillin-resistant Staphylococcus aureus (Gram-positive). Also, to investigate the antibiofilm activity of the most potent extract. From all tested plants, the total extract of $Z$. spina-christi appeared a strong antibacterial effect against all tested MDR-strains. Besides, its polyphenol fraction showed a stronger effect. Furthermore, the total extract MIC ranged between $3.125-12.5 \mathrm{mg} / \mathrm{ml}$ with MBC was 3.125-25 $\mathrm{mg} / \mathrm{ml}$ against previous strains. While, polyphenol fraction MIC and MBC were about 0.312$1.25 \mathrm{mg} / \mathrm{ml}$ and $0.312-2.5 \mathrm{mg} / \mathrm{ml}$, respectively. In contrast to the antibacterial strength of polyphenol fraction, the antibiofilm effect was weaker than the total extract antibiofilm effect, where at $1 / 2 \mathrm{MIC}$, the reduction of biofilm was about $\mathbf{7 8 . 1 8 \% , 8 1 . 9 \%}$ and $\mathbf{9 9 . 4 8 \%}$ against $S$. aureus, MRSA and $P$. aeruginosa, respectively. While, in the case of polyphenol fraction, the biofilm reduction effect against previous strains was $63.82 \%, 59.97 \%$, and $87.95 \%$, respectively.
\end{abstract}

Keywords: Herbal extracts, Medicinal plants, Antimicrobial agent, MDR-bacteria, MRSA

*Correspondence: ahmed_sofy@azhar.edu.eg; ahmd_sofy@yahoo.com

(Received: January 12, 2020; accepted: March 21, 2020)

Citation: Ahmed R. Sofy, Akram A. Aboseidah, El-Shahat El-Morsi, Heba A. Azmy and Ahmed A. Hmed, Evaluation of Antibacteria and Antibiofilm Activity of new Antimicrobials as an Urgent Need to Counteract Stubborn Multidrug-resistant Bacteria, J. Pure Appl. Microbiol., 2020; 14(1):595-608. https://doi.org/10.22207/JPAM.14.1.62

(C) The Author(s) 2020. Open Access. This article is distributed under the terms of the Creative Commons Attribution 4.0 International License which permits unrestricted use, sharing, distribution, and reproduction in any medium, provided you give appropriate credit to the original author(s) and the source, provide a link to the Creative Commons license, and indicate if changes were made. 


\section{INTRODUCTION}

Multiple drug-resistant bacteria (MDRBs)

are one of the world's most serious health risks, and new anti-infective drugs are required to address them ${ }^{1}$. They arise when bacteria can live in the presence of drugs that would usually hinder their development ${ }^{2}$. The rapid development of bacterial antibiotic resistance is a disturbing aspect of systemic infections that can quickly worsen without effective treatment ${ }^{3}$. There is therefore an urgent need to develop new classes of antibiotics which are not affected by the resistance mechanism already in place in the bacterial population due to the increased antibiotic resistance of clinically relevant bacteria ${ }^{4}$. In addition, new anti-infective products are needed to work through new mechanisms for action ${ }^{5}$. Plants are a good source of natural products for discovering bioactive compounds ${ }^{6}$. The study of alternative mechanisms for antibiotic resistance could open up new ways to develop antibiotic resistance ${ }^{5}$, and natural products could be a critical antibiotic reservoir to overcome antibiotic resistance mechanisms ${ }^{7}$.

A complex aggregation of microbes forms a bacterial biofilm, in which the cells are enclosed with an extracellular polymeric substance (EPS) (self-produced). Biofilm development through bacterial adhesion to human tissues and medical devices is a significant virulence factor linked to increased antibiotic resistance, decreased phagocytosis and overall microorganism continuation ${ }^{8}$. Biofilm inhibitors do not influence cell growth and there is a lower risk of developing resistance. Since biofilms play an essential role in bacterial pathogenesis and drug tolerance, biofilm inhibitors may help to fight infectious diseases ${ }^{9}$. Therefore, the aim of the current study is the isolation of the most multidrug-resistant bacterial strains, with an attempt to overcome these resistant microorganisms via screening of the antibacterial activity of five medicinal plants named, Nigella sativa, Ziziphus spina-christi, Rosmarinus officinalis, Origanum majorana, and Allium sativum. Also, affecting the biofilm activity of most biofilm-producing strains using the most potent plant extract.

\section{MATERIAL AND METHODS \\ Bacterial strains}

Two hundred and fifty (250) bacterial strains including Gram-negative (GN) and Gram-positive (GP) strains were provided by Suez General Hospital, Egypt. All strains were immediately transported in the sterilized box into the bacteriology laboratory.

\section{Culture condition and maintenance media}

The provided bacterial strains were propagated and subcultured at $37^{\circ} \mathrm{C}$ for $24 \mathrm{~h}$ on different media including Muller-Hinton broth, Nutrient agar medium, Trypticase soy agar, Mannitol salt agar, Blood agar base medium and Muller-Hinton agar then the pure colony was kept on agar slant before carrying out the tests for antibiotic sensitivity profile, identification and antimicrobial assays.

\section{Antibiotic sensitivity test of bacterial isolates}

Seventeen commercially prepared $(6$ $\mathrm{mm}$ in diameter) antibiotic disks, obtained from Oxoid, UK, belonging to a variety of groups, were selected for their potency against bacterial isolates. Properties of the target antibiotics included: Ampicillin (10 mcg), Flucloxacillin (5 $\mathrm{mcg}$ ), Clindamycin (2 mcg), Levofloxacin (5 mcg), Erythromycin $(15 \mathrm{mcg})$, Kanamycin $(30 \mathrm{mcg})$, Tobramycin (10 mcg), Ofloxacin (5 mcg), Rifamycin (30 mcg), Aztreonam (1 mcg), Gentamicin (10 $\mathrm{mcg})$, Norfloxacin $(10 \mathrm{mcg})$, Gatifloxacin $(5 \mathrm{mcg})$, Cephradine $(30 \mathrm{mcg})$, Tetracycline $(30 \mathrm{mcg})$, Ciprofloxacin $(5 \mathrm{mcg})$ and Oxacillin $(1 \mathrm{mcg})$. The test was performed according to the standard Kirby-Bauer disk diffusion method ${ }^{10}$. The findings were presented according to standardized protocols for the assay of antibiotic compounds as directed by National Committee for Clinical Laboratory Standards "NCCLS", and were classified as sensitive (S), intermediate sensitive (I) and resistant $(R)^{11}$.

\section{Primary identification of bacterial isolates}

According to Bergey's manual, almost all microscopically examinations and biochemical testing used for identification were carried out ${ }^{12,13}$.

\section{Secondary identification}

It was by automated identification using the Biomerieux Vitek 2 System. The procedure of the identification was used according to the recommendations of the manufacturer. The databases of the VITEK 2 identification based 
on established biochemical methods and newly developed substrates, according to Funke and Funke-Kissling ${ }^{14,15}$.

\section{Plant materials}

Different parts of 5 medicinal plants, including Nigella sativa (seeds), Ziziphus spinachristi (leaves), Rosmarinus officinalis (leaves and stem), Origanum majorana (leaves) and Allium sativum (fruit). Plant parts were obtained from Ain Shams Uni., where the collected plant parts were cleaned, washed, and shade dried, exposure to sunlight was avoided to prevent the loss of active components. Dried plant parts were homogenized to a fine powder and stored in airtight bottles ${ }^{16}$.

\section{Aqueous extract preparation}

The fine powder of different plants parts weighing $100 \mathrm{lg}$ ) was extracted with one liter of distilled water $(1: 10 \mathrm{w} / \mathrm{v})$ in a conical flask, plugged with cotton wool, and then kept for 7 days, by means of cold extraction. Then the extract was filtered with 8 layers of muslin cloth. The extract of each plant was concentrated in vacuo using a rotary evaporator at $40^{\circ} \mathrm{C}$. The water remaining in the extract was finally removed by placing the extract in porcelain dishes in the temperaturecontrolled oven to give a residue weighing about 6.3-9.2 g for different extracts. The residues were stored at $4^{\circ} \mathrm{C}$ for further use ${ }^{17,18}$

Acid-Base fractionation of most potent plant extract

About (100g) of Z. spina-christi plant powder was extracted with one liter of distilled water. The water extract of the plant was concentrated under reduced pressure until dryness at a temperature not exceeding $60^{\circ} \mathrm{C}$, acidified with $\mathrm{HCl} 3 \%$ until $\mathrm{pH}=1.5$ and then filtered. The filtrate obtained was transferred to separated funnel, and the chloroform $(\mathrm{v} / \mathrm{v})$ was added to the filtrate and left for $10-15 \mathrm{~min}$ after proper mixing, two layers were formed (upper layer was chloroform layer "acid-alkaloid fraction") and (lower layer was aqueous layer), the previous step repeated about three times until the upper layer become colorless. The aqueous layer was transferred to separated funnel and ammonia was added to adjust the medium until $\mathrm{pH}=10.5$, then chloroform in ( $\mathrm{v} / \mathrm{v})$ was added and two layers formed, the upper chloroform layer ("Base alkaloid fraction") and the aqueous lower layer ("rich polyphenol fraction"). The previous step was repeated about three times until the upper layer become colorless. The fractions were filtered and evaporated under reduced pressure until dryness then weighed to calculate the percent $(\mathrm{w} / \mathrm{w})^{19}$.

Investigation of antibacterial activity of plant extracts

Test organisms

The most Multidrug-resistant bacterial strains namely, Klebsiella pneumoniae (Gramnegative), Escherichia coli (Gram-negative), Pseudomonas aeruginosa (Gram-negative), Staphylococcus aureus (Gram-positive) and Methicillin-resistant Staphylococcus aureus (Gram-positive) which isolated from the clinical specimens were selected for the study of antibacterial and antibiofilm assays of used extracts.

Seeding method for the bacterial strains under study

In a $150 \mathrm{ml}$ conical flask containing 25 $\mathrm{ml}$ of Muller Hinton Broth, a loop full of each strain was inoculated, followed by incubation in a rotary shaker at room temperature for 24 hours to activate the bacteria with a final cellular concentration of $1 \times 10^{8} \mathrm{cfu} / \mathrm{ml}$. The molten Mueller Hinton Agar was inoculated with an inoculum of $200 \mu \mathrm{l}$ and poured into the sterilized petri dishes where precaution was taken to ensure full homogenization ${ }^{20}$.

Preparation of the extracts for antibacterial assay

Plant extracts were dissolved in sterile distilled water for antibacterial study. The concentration of the extracts was evaluated and labeled on the specified tube. The antibacterial study of different plant extracts was assayed by two methods as follows:

\section{Disc diffusion method}

The disc diffusion method was performed for the determination of antimicrobial of the five tested extracts against previous mentioned MDR-strains. A standard blank paper disk (7 $\mathrm{mm}$ in diameter) were separately soaked in high concentrations of extracts $(100 \mathrm{mg} / \mathrm{ml})$ and transferred onto the surface of growth media previously seeded with the test organisms in petri plates using a sterile pair of forceps. The Petri dishes were closed with parafilm and left in the refrigerator for 1 hour to allow the active compounds of the extracts diffuse. Sterile distilled water was used as a negative control instead of active compounds. The plates were then incubated 
at $37^{\circ} \mathrm{C}$ for 24 hours. By calculating the diameter of the inhibition zones in millimeters around the disc using a caliper or ruler, the sensitivity of the bacteria to each extract was determined when the values were reported as an average of three replicates ${ }^{21}$.

Broth microdilution method [Mean growth inhibition percentage (\%)]

The bacterial suspension equivalent to the turbidity of $0.5 \mathrm{McF}$ arland standard $\left(10^{8} \mathrm{cfu} /\right.$ $\mathrm{ml}$ ) prepared from a fresh subculture of tested bacteria in Mueller Hinton Broth (MHB), then the suspension was diluted to $\left(10^{6} \mathrm{cfu} / \mathrm{ml}\right)$ using $\mathrm{MHB}$. The adjusted microbial inoculums (100 $\mu \mathrm{L})$ were added to each well of a sterile 96-well flatbottomed microtiter plate containing the tested concentration $100(\mathrm{mg} / \mathrm{ml})$ of each plant extract 100 ( $\mu \mathrm{L} /$ well). As a result, the last inoculum concentration of $\left(5 \times 10^{5} \mathrm{CFU} / \mathrm{ml}\right)$ was obtained in each well. This plate included two wells containing only the media used as background control and three wells containing microbial suspension without the extract tested used as growth control. The optical density was assessed at $620 \mathrm{~nm} 37^{\circ} \mathrm{C}$ after 24 hours using ELISA microplate reader (Sunrise $^{\text {TM }}$-TECAN, Switzerland) at the Department of Botany and, Faculty of Science, Al-Azhar University, Cairo, Egypt. Ampicillin and Gentamicin were used as standard antibiotics for Grampositive and Gram-negative bacteria, respectively. Finally, cell concentrations were transformed into a percentage of bacterial inhibition. The percentage of bacterial growth reduction (GR $\%)$ was calculated using GR\%= as reference the control treatment (without extract). Since $T$ is the concentration of cells under the extract treatment, and $C$ is the concentration of cells under the control treatment. The results were reported as means $\pm S E$ of the triplicate experiment ${ }^{11}$.

Determination of (MICs) and (MBCs) of the most potent plant extract and its polyphenol fraction

Using the broth microdilution method, the MICs of total extract and polyphenol fraction of Z. spina-christi was performed in 96 polystyrene wells according to Andrews ${ }^{22}$ and Sampaio, et $a l^{23}$. For each bacterial strain, an inoculum suspension contains a cell concentration of $10^{8} \mathrm{CFU} / \mathrm{mL}$ was prepared in Mueller-Hinton broth. In the test each wells of the plate $20 \mu \mathrm{l}$ of tested plant extract was added to a $180 \mu$ of bacterial suspension. For tested extracts which, diluted to yield concentrations $50,25,12.5,6.25$, 3.125 and $1.562 \mathrm{mg} / \mathrm{ml}$ for total extract and 5, $2.5,1.25,0.626,0.312,0.156$ and $0.078 \mathrm{mg} /$ $\mathrm{ml}$ for polyphenol portion of Z. spina-christi. In plate setup both control positive wells (Media + bacteria) and control negative wells (media + tested extract) as well as a background wells (media + sterile distilled water) were contained. The highest dilution of the tested extract (lowest conc.) inhibit the visible bacterial growth defined as the MIC ${ }^{11}$. After determination of MICs of Z. spina-christi total extract and its polyphenol fraction against each bacterial strain, the wells of MICs were poured on the surface of Muller- Hinton agar plates and then incubated at $37^{\circ} \mathrm{C}$ for $24 \mathrm{~h}$. After incubation the developed bacterial colonies were counted and the lowest concentration of the tested extract showed bactericidal effect (no growth) was defined as minimum bactericidal concentration (MBC).

Biofilm Formation of MDR-bacterial isolates

Quantitative assessment was carried out using the Microplate method (MP) suggested by Christensen, et al. ${ }^{24}$ using 96 flat bottom well tissue culture plates. For determination of biofilm formation activity of $S$. aureus, MRSA and $P$. aeruginosa the wells of microtiter plates were loaded by $0.2 \mathrm{ml}$ of bacterial inoculum $\left(10^{5}\right.$ CFU/ml) in Trypticase soya broth (TSB) medium containing $2 \%$ glucose (Glc), the plates were aerobically incubated for $24 \mathrm{~h}$ at $37^{\circ} \mathrm{C}$ and then twice washed by PBS ( $\mathrm{pH}$ 7.2). After washing $0.1 \%$ crystal violet (CV) was added onto the wells to staining for $2 \mathrm{~min}$. The plates were measured at $570 \mathrm{~nm}$ using ELISA microplate reader (Sunrise ${ }^{\mathrm{TM}}$ TECAN, Switzerland). Negative control wells (sterile media) also contained in the plates. The vales of the different optical density (OD) were calculated to detect the slime producing strains (biofilm formers) in comparison with O.D. of negative control or cut off. The interpretation of the production of biofilm was made in accordance with the criteria set out by Stepanovic, et al. ${ }^{25}$. Antibiofilm formation activity of most potent plant extract and its polyphenol fraction

Sub-MICs of total extract and polyphenol fraction of $Z$. spina-christi at concentrations 2, 1 , 0.5 and $0.25 \mathrm{mg} / \mathrm{ml}$ and 200, 100, 50, and $25 \mu \mathrm{g} /$ $\mathrm{ml}$, respectively were checked for their ability to 
inhibit biofilm formation in biofilm-producing strains. At the time of inoculation, they were added to the growth medium and the cells were allowed to form a biofilm. Two-fold serial dilutions of aliquot $(100 \mu \mathrm{L})$ were prepared in a 96-well microtiter TSBGlc-containing plate containing different concentrations of extracts tested under the MIC values. Bacterial suspensions $(100 \mu \mathrm{L}$; $5 \times 10^{5} \mathrm{CFU} / \mathrm{mL}$, final concentration) were then transferred into the plate. The wells of TSBGlc medium with $0.2 \%$ DMSO was used as a negative control, while the wells of the medium without tested extracts serve as positive control and wells of different concentrations of tested extracts acts as a blank. The plates were placed in incubated shaker in aerobic condition for $24 \mathrm{~h}$ at $37^{\circ} \mathrm{C}$. After the incubation period the effect of each extract concentration was measured at O.D. $570 \mathrm{~nm}$ using the microplate reader (Sunrise ${ }^{\mathrm{TM}}$-TECAN, Switzerland) against the biofilm activity of $S$. aureus, MRSA and $P$. aeruginosa according to the previously mentioned method ${ }^{26}$. In addition, the growth of the tested strains without the extracts was also determined at O.D. of $620 \mathrm{~nm}$. The experiment was performed in triplicate.

\section{RESULTS \\ Bacterial isolates}

Two hundred and fifty (250) bacterial isolates were isolated from collected clinical specimens from various clinical sources. Out of 250 isolates, 68 were resistant to most tested antibiotics from different groups including (Ampicillin, Flucloxacillin, Clindamycin, Levofloxacin, Erythromycin, Kanamycin, Tobramycin, Ofloxacin, Rifamycin, Aztreonam, Gentamicin, Norfloxacin, Gatifloxacin, Cephradine, Tetracycline, Ciprofloxacin, and Oxacillin) and represented about $27.2 \%$. Only 29 isolates showed complete resistance to all tested antibiotics and represented about $11.6 \%$ of the total isolates.

3.2. Identification of bacterial isolates

All of 29 multidrug-resistant bacterial were identified by conventional morphological methods (Colonial morphology, Gram's stain) and biochemical characteristics. The results obtained from primary identification indicated that there are five different groups of MDR- bacterial isolates. The isolates were identified as Klebsiella pneumoniae, Escherichia coli, Pseudomonas aeruginosa,
Staphylococcus aureus, and Methicillin resistantStaphylococcus aureus (MRSA) with excellent probability after full biochemical identification by VITEK2 system for confirming the identification. These MDR-isolates belonged to four genera and included, 13 isolates $(44.82 \%)$ of $K$. pneumonia, $8(27.58 \%)$ of $E$. coli, 5 (17.24\%) of P. aeruginosa, $3(10.34 \%)$ of $S$. aureus and only one (3.44\%) of MRSA (Fig. 1).

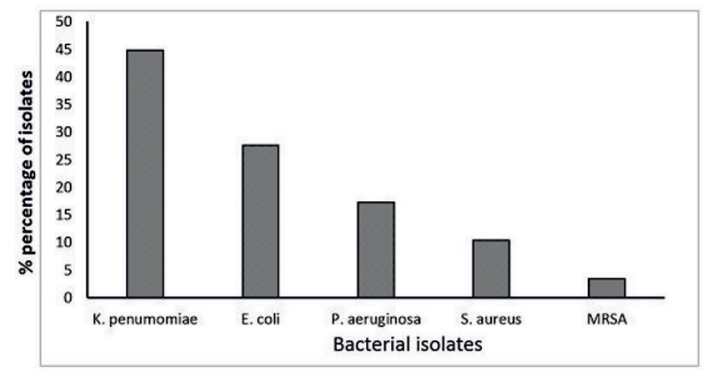

Fig. 1. Percentages (\%) of identified MDR-bacteria from clinical specimens

\section{Antibacterial activity of used plant extracts against MDR- bacterial isolates}

In this study, the aqueous extract of different medicinal plants individually was used for assaying their biocontrol activity against MDR- bacterial isolates, including (Nigella sativa, Ziziphus spina-christi, Rosmarinus officinalis, and Origanum majorana and Allium sativum).

\section{Primary screening of antibacterial activity}

In the present study, antibacterial screening tests at high concentrations (100 $\mathrm{mg} / \mathrm{ml}$ ) of different aqueous crude extracts by both paper disc diffusion and mean growth inhibition percentage using microdilution assay were performed against $K$. pneumonia, E. coli, $P$. aeruginosa, S. aureus, and Methicillin resistant-S. aureus (MRSA), which previously determined as the most resistant strains.

From the obtained results, the extract of Ziziphus spina-christi was most potent extract where exhibit lethal activity against all tested MDR-bacterial strains with inhibition zone $17 \pm 1.2$ $-23.6 \pm 0.86 \mathrm{~mm}$ in diameter on agar plates by disc diffusion assay and $100 \%$ growth inhibition percentage against all strains (Table 1 \& Fig. 2).

Origanum majorana aqueous extract was the second strong extract exhibit antibacterial activity with inhibition zone $10.53 \pm 0.73-19.4 \pm 0.88$ $\mathrm{mm}$ in diameter and $68.4 \pm 0.66-100 \%$ growth 


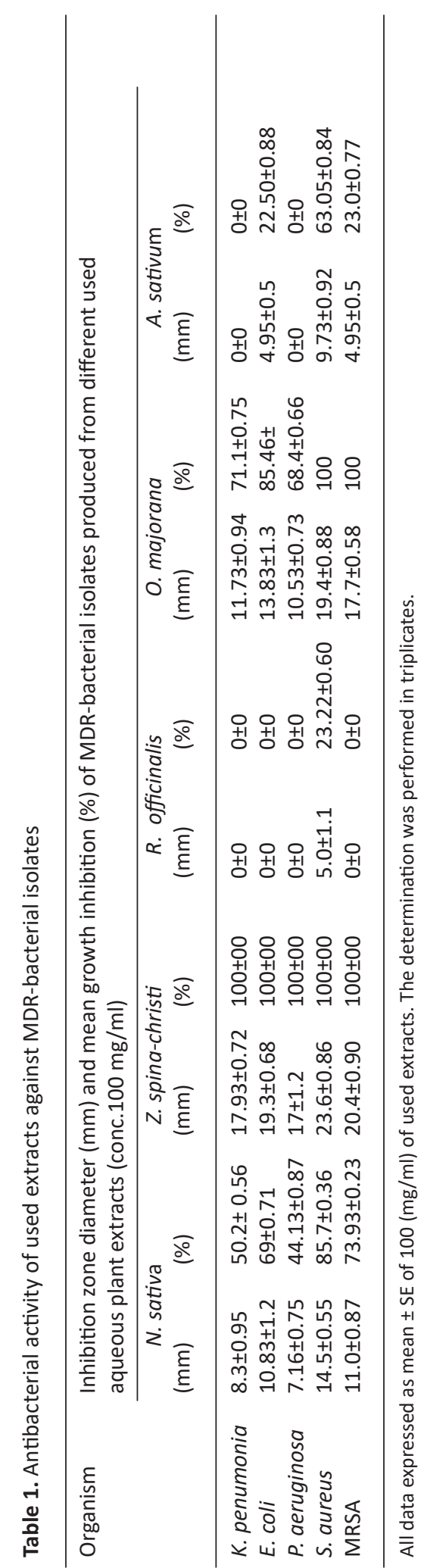

inhibition percentage against tested MDR-bacterial strains (Table 1 \& Fig. 2).

Nigella sativa showed moderate antibacterial activity with inhibition zone was7.16 $\pm 0.75-14.5 \pm 0.55 \mathrm{~mm}$ in diameter on agar plates by disc diffusion assay and $44.13 \pm 0.87$ $85.7 \pm 0.36 \%$ growth inhibition percentage against all strains (Table $1 \&$ Fig. 2).

Allium sativum extracts exhibit low effect against the MDR-E. coli and MRSA cells with inhibition zone $4.95 \pm 0.5$ and $4.95 \pm 0.5 \mathrm{~mm}$ in diameter respectively, as well as, $22.50 \pm 0.88$ and $23.0 \pm 0.77 \%$ of cells growth inhibition, respectively. While its antibacterial activity showed moderate influence against $S$. aureus with inhibition zone $9.73 \pm 0.92 \mathrm{~mm}$ in diameter and $63.05 \pm 0.84 \%$ of mean growth inhibition of the cells. On the other hand, the same extract exhibits no lethal activity against $K$. pneumoniae and $P$. aeruginosa (Table $1 \&$ Fig. 2).

In contrast to the above, Rosmarinus officinalis had no antibacterial effect against all tested MDR- bacterial strains except in the case of $S$. aureus, where it showed a low effect, with inhibition zone $5.0 \pm 1.1 \mathrm{~mm}$ in diameter and $23.22 \pm 0.60$ of cells growth inhibition (Table 1 \& Fig. 2).

Screening of antibacterial activities of Acid-Base fractions of Ziziphus spina-christi

Ziziphus spina-christi aqueous extract was undergone acid-base fractionation into three portions (Polyphenols, acidic- alkaloids, and basicalkaloids fractions) to investigate the most potent fraction which attributed to the antibacterial activity.

The antibacterial activity of the three fractions was assessed by disc diffusion and broth microdilution methods against MDR-bacterial isolate, both inhibition zone diameter $(\mathrm{mm})$ and mean growth inhibition percentage (\%) were also determined.

Poly phenols fraction of $Z$. spina-christi showed the strongest antibacterial activity against tested MDR-bacteria isolates, compared with the rest of the other fractions where exhibit complete growth inhibition towards tested MDR-strains with inhibition zones diameter produced from the polyphenols impregnated discs were $30.87 \pm 1.15$ $43.7 \pm 0.77 \mathrm{~mm}$ in diameter and $100 \pm 0.0$ of cells growth inhibition (Table 2 and Figure 3). As well as, 


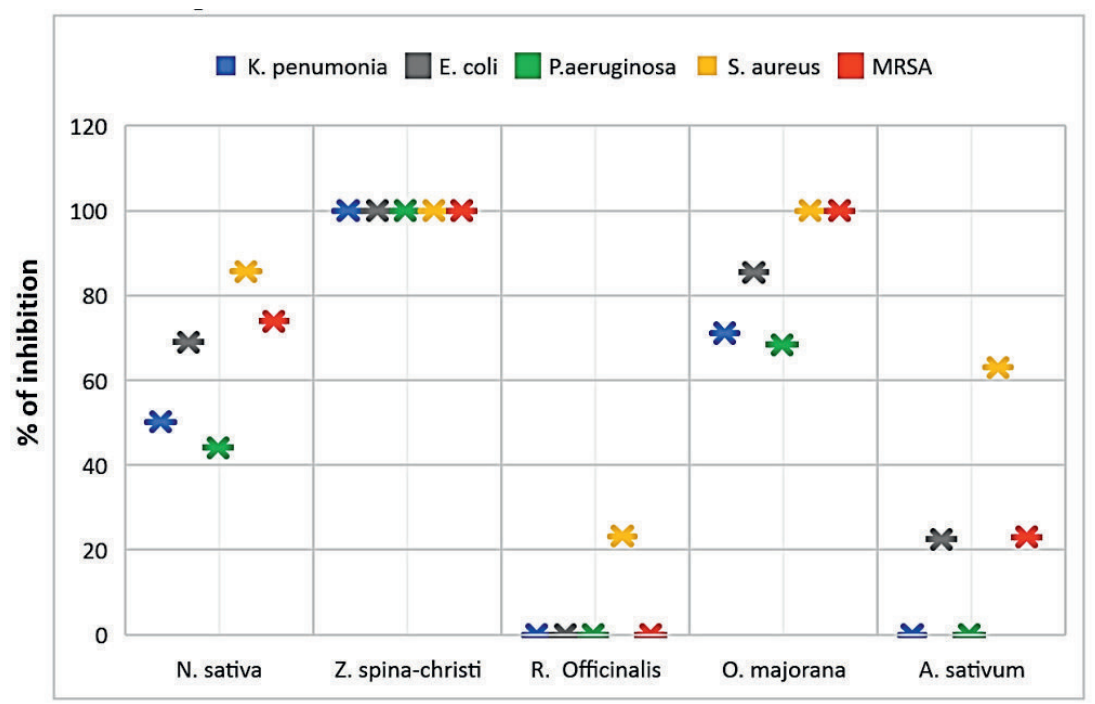

Fig. 2. Antibacterial activities of used plant extracts against tested MDR-bacteria

the antibacterial activity of polyphenols fraction of Z. spina-christi was stronger than the activity of its total extract (Fig. 4). These results indicated that the antibacterial activity of $Z$. spina-christi might be attributed to its phenolic compounds. Although the basic-alkaloids fraction showed antibacterial activity, it was much less than the polyphenols fraction effect where showed moderate influence against tested organisms with inhibition zones diameter 8.31 $\pm 1.3-12.0 \pm 1.1 \mathrm{~mm}$ and $45.61 \pm 0.39$ $71.88 \pm 0.60 \%$ of mean cells growth inhibition (Table 2 \& Fig. 3).

The impregnated discs and mean growth inhibition percentages showed no inhibitory effect in the presence of acidic-alkaloids fraction against all tested bacterial isolates (Table 2 \& Fig. 3).

MIC and MBC of Ziziphus spina-christi Both minimum inhibitory concentration and minimum bactericidal concentration were determined for both the Z. spina-christi total extract and its polyphenol fraction.

\section{MICs and MBCs of total extract}

The obtained results showed that MICs and MBCs against tested MDR-bacterial isolates were concentration-dependent. It was found that $K$. pneumoniae and $P$. aeruginosa were the strains exhibited cells inhibition and killing at little higher MICs and MBCs in equal quantities of $12.5 \mathrm{mg} / \mathrm{ml}$ and $25 \mathrm{mg} / \mathrm{ml}$ for both of them respectively, from Z. spina-christi total extract (Table 3 \& Figs 5 \& 6).

The highest activity with the lowest MICs of $3.125 \mathrm{mg} / \mathrm{ml}$ was recorded against S. aureus and MRSA. As well as, the results of the current study showed that MBCs against the two previous Gram-positive bacterium type were at the same concentration $(3.125 \mathrm{mg} / \mathrm{ml})$, indicating that, at

Table 2. Antibacterial activity of Acid-Base fractionations of Z. spina-christi against MDR-bacterial isolates

\begin{tabular}{|c|c|c|c|c|c|c|}
\hline \multirow{2}{*}{ Organism } & \multirow{2}{*}{$\begin{array}{l}\text { Polyphenol } \\
\text { fraction } \\
(\mathrm{mm})\end{array}$} & \multicolumn{5}{|c|}{ Acid-Base fractionations of $Z$. spina-christi } \\
\hline & & \multicolumn{3}{|c|}{$\begin{array}{l}\text { Acidic-alkaloid fraction } \\
\begin{array}{ll}(\%) & (\mathrm{mm})\end{array}\end{array}$} & \multicolumn{2}{|c|}{$\begin{array}{l}\text { Basic- alkaloid fraction } \\
(\mathrm{mm})\end{array}$} \\
\hline K. penumonia & $31.2 \pm 0.95$ & $100 \pm 00$ & $0 \pm 0$ & $0 \pm 0$ & $9.0 \pm 0.95$ & $47.37 \pm 0.44$ \\
\hline E. coli & $36.0 \pm 1.2$ & $100 \pm 00$ & $0 \pm 0$ & $0 \pm 0$ & $10.77 \pm 0.87$ & $68.9 \pm 0.76$ \\
\hline P. aeruginosa & $30.87 \pm 1.15$ & $100 \pm 00$ & $0 \pm 0$ & $0 \pm 0$ & $8.31 \pm 1.3$ & $45.61 \pm 0.39$ \\
\hline S. aureus & $43.7 \pm 0.77$ & $100 \pm 00$ & $0 \pm 0$ & $0 \pm 0$ & $12.0 \pm 1.1$ & $71.88 \pm 0.60$ \\
\hline MRSA & $39.5 \pm 0.97$ & $100 \pm 00$ & $0 \pm 0$ & $0 \pm 0$ & $10.93 \pm 0.96$ & $70 \pm 0.85$ \\
\hline
\end{tabular}

All data expressed as mean \pm SE of $100(\mathrm{mg} / \mathrm{ml})$ of acid-base fractions. The determination was performed in triplicates. 


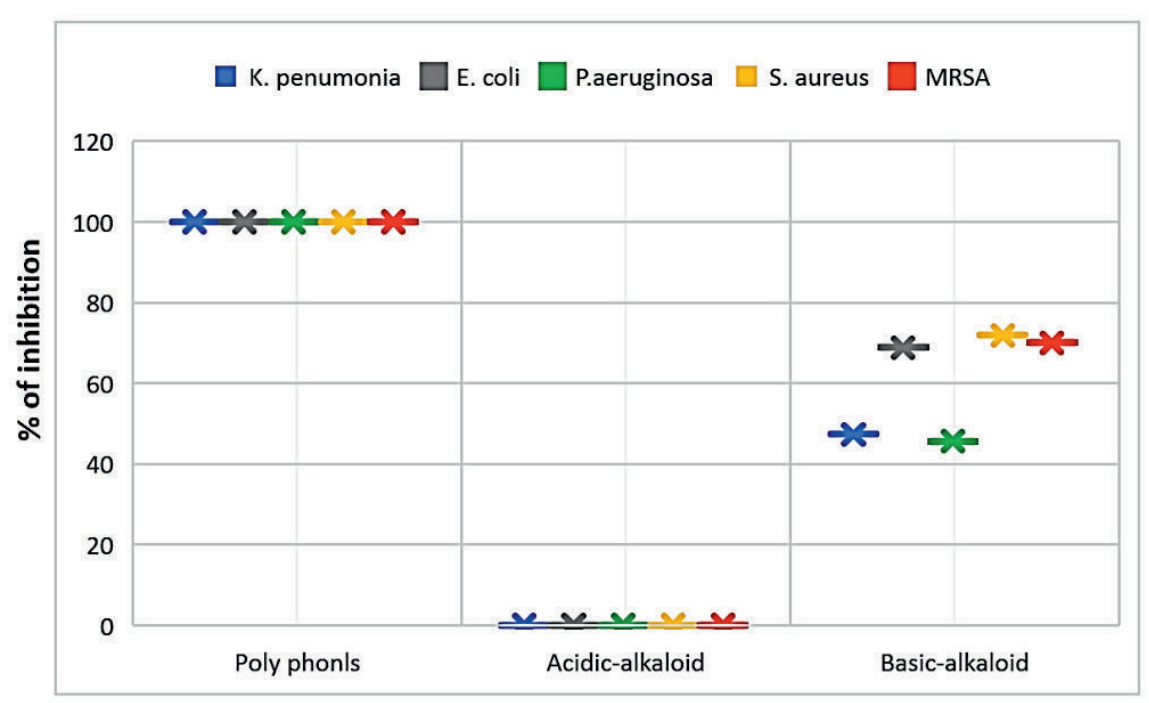

Fig. 3. Antibacterial activities of Acid-Base fractions of Ziziphus spina-christi against tested MDR-bacteria

this concentration, the action was bactericidal not bacteriostatic (Table 3 and Figs 5 \& 6).

The MIC of $6.25 \mathrm{mg} / \mathrm{ml}$ was reported for MDR-E. coli strain while, more extract concentration required for the cidal action with $12.5 \mathrm{mg} / \mathrm{ml}$ as MBC value (Table 3 and Figures 5 \&6).

\section{MICs and MBCs of polyphenol fraction}

Table (3) and figures (5 \& 6) represent the comparative MICs, and MBCs values of the polyphenol portion of $Z$. spina-christi extract against the five tested MDR-bacterial strains.

It is evident from the results, polyphenol fraction of $Z$. spina-christi extract possessed the most significant antibacterial activity against previous resistant strains so, low concentrations required for inhibition as well as for killing the previous resistant strains. $K$. pneumoniae $\mathrm{MIC}$ and $\mathrm{MBC}$ were in equal quantities with $1.25 \mathrm{mg} / \mathrm{ml}$ while, the effect of this fraction against $P$. aeruginosa at $1.25 \mathrm{mg} / \mathrm{ml}$ was bacteriostatic and recorded as the MIC value, but to achieve the bactericidal action the concentrations of the increase are required at $2.5 \mathrm{mg} / \mathrm{ml}$ which considered as $\mathrm{MBC}$ value (Table 3 and Figs 5 \& 6). E. coli presented growth inhibition at $0.625 \mathrm{mg} / \mathrm{ml}$ as MIC value; however, the $\mathrm{MBC}$ was recorded at $1.25 \mathrm{mg} /$ $\mathrm{ml}$ (Table 3 and Figs $5 \& 6$ ). S. aureus and MRSA presented the lowest growth inhibition effect of the polyphenol fraction, and the MIC likewise, $\mathrm{MBC}$, were in equal quantities with $0.312 \mathrm{mg} / \mathrm{ml}$ (Table 3 and Figs 5 \& 6).

These results indicate that $Z$. spina-christ total extract also, its polyphenol fraction, could be developed as an active antimicrobial agent against tested multidrug-resistant bacteria, which cannot be treated by lots of antibiotics.

Table 3. MIC and MBC of $Z$. spina-christi total extract and its polyphenol fraction

\begin{tabular}{lccccc}
\hline \multirow{2}{*}{ Organism } & \multicolumn{4}{c}{ Z. spina-christi } \\
& \multicolumn{2}{c}{ Total extract } & & Poly phenols fraction \\
\cline { 2 - 3 } \cline { 5 - 6 } & MIC & MBC & & MIC & MBC \\
\hline K. penumonia & $12.5 \pm 0.74$ & $25 \pm 1.2$ & & $1.25 \pm 0.43$ & $1.25 \pm 0.58$ \\
E. coli & $6.25 \pm 0.64$ & $12.5 \pm 0.91$ & & $0.625 \pm 0.96$ & $1.25 \pm 0.64$ \\
P. aeruginosa & $12.5 \pm 0.96$ & $25 \pm 0.96$ & & $1.25 \pm 1.2$ & $2.5 \pm 0.73$ \\
S. aureus & $3.125 \pm 1.1$ & $3.125 \pm 0.77$ & & $0.312 \pm 1.2$ & $0.312 \pm 0.66$ \\
MRSA & $3.125 \pm 0.78$ & $3.125 \pm 0.95$ & $0.3 .12 \pm 0.82$ & $0.312 \pm 0.77$ \\
\hline
\end{tabular}

Values are mean $\pm \mathrm{SE}$ of triplicate assays. 


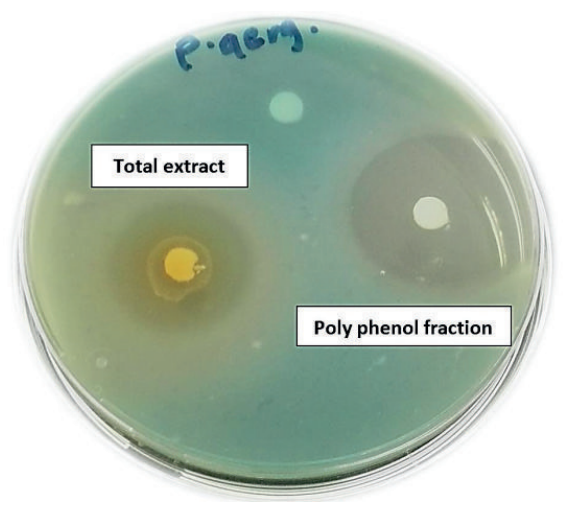

Fig. 4. Antibacterial activities of $Z$. spina-christi total extract and its polyphenol fraction against MDR-P. aeruginosa

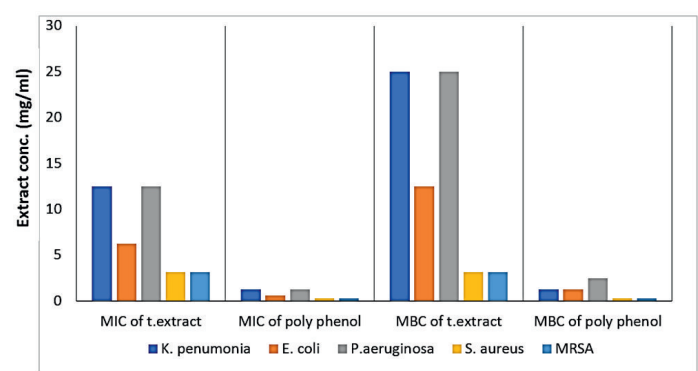

Fig. 5. MICs and MBCs of total extract and polyphenol fraction of Ziziphus spina-christi against tested MDRbacterial strains

\section{Biofilm formation as virulence factors of isolated MDR-strains}

Biofilm is one of the essential virulence characters of pathogenic strains, so in this study, biofilm formation activity of all tested clinical isolates was examined by the quantitative method to select the most virulent isolates.

A positive biofilm phenotype was defined as $O D \geq 0.17$ at $570 \mathrm{~nm}$ (O.D. 570). Interpretation of biofilm production, strong biofilm formation was classified as 0.7 (O.D. 570) to 1.0 (O.D. 570), moderate biofilm formation was 0.3 (O.D. 570) to 0.4 (O.D. 570) and weak biofilm $\geq 0.3$ (O.D. 570). Depending on our findings, the tested MDRbacterial strains showed different biofilm formation activities (Figure 7). Among the tested biofilm strains, $S$. aureus and $P$. aeruginosa strains were the most biofilm virulent strains, and their biofilm was very active 1.288 (O.D. 570) and 1.162 (O.D. 570), respectively (Table 4). The following active biofilm was by MRSA strain with 0.982 (O.D. 570), and its biofilm classified as strong. In the second direction, E. coli has a moderate biofilm degree with 0.432 (O.D. 570) while, K. penumoniae exhibited a weak biofilm formation with 0.121 (O.D. 570) (Table 4).

Table 4. Determination of biofilm formation by tissue culture plate method

\begin{tabular}{lccc}
\hline Strain & $\begin{array}{c}\text { Growth } \\
\text { (O.D. } 620 \mathrm{~nm})\end{array}$ & $\begin{array}{c}\text { Biofilm } \\
\text { (O.D. } 570 \mathrm{~nm})\end{array}$ & Interpretation \\
\hline K. pneumoniae & 0.7 & 0.121 & Weak \\
E. coli & 0.9 & 0.432 & Moderate \\
P. aeruginosa & 1.7 & 1.162 & Strong \\
S. aureus & 1.2 & 1.288 & Strong \\
MRSA & 1.3 & 0.982 & Strong \\
\hline
\end{tabular}

$\mathrm{OD}=$ Optical density

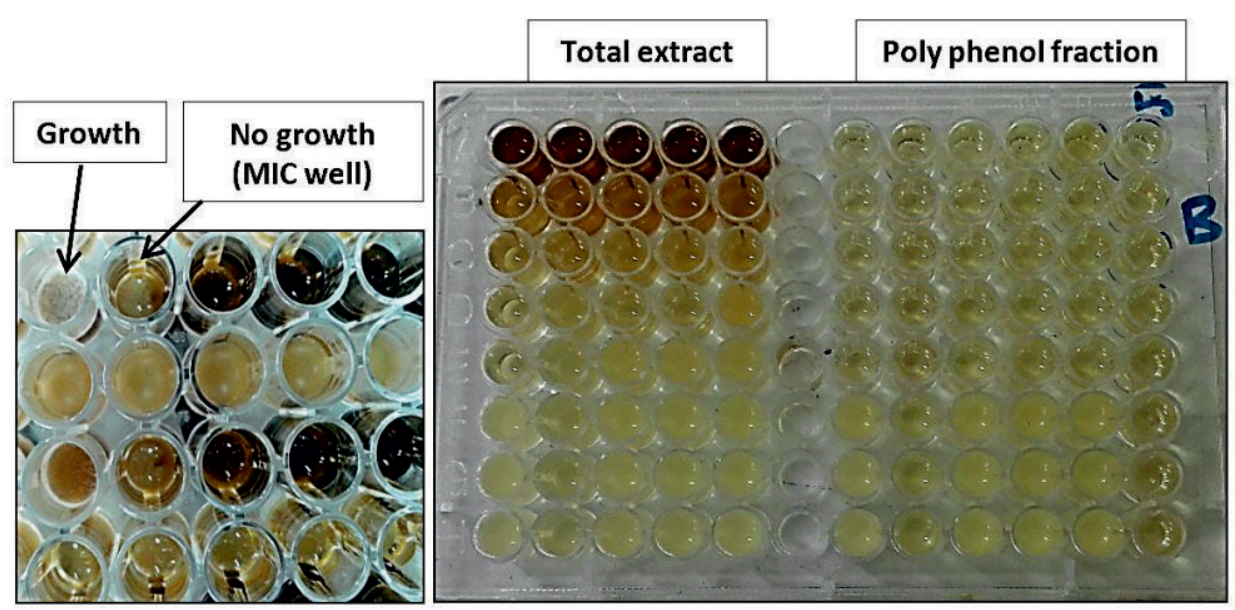

Fig. 6. MICs of total extract and polyphenol fraction of Z. spina-christi against tested MDR-bacterial isolates using the microdilution method 
Effect of sub-MICs of total extract and polyphenol fraction of $Z$. spina-christi on $P$. aeruginosa, $S$. aureus, and MRSA biofilms

Doses of sub-MICs of total extract and polyphenol fraction of Z. spina-christi were investigated against strong biofilm-producing strains (S. aureus, P. aeruginosa, and MRSA). It was found that $Z$. spina-christi total extract at sub-MICs exhibited a strong reduction effect against tested MDR-strains than the effect of polyphenol fraction at sub-MICs (Tables 5, 6, 7 \& 8).
Against $S$. aureus and MRSA strains biofilms

At $1 / 2$ MIC, both $S$. aureus and MRSA biofilm were strongly affected by $78.18 \%$ and $81.9 \%$, respectively, using the total extract of $Z$. spina-christi. While other sub-MICs exhibited moderate to weak effects (Table 5 and Figs 8 \& 9).

On the other hand, polyphenol fraction at $1 / 2$ MIC showed only moderate effect against the $S$. aureus and MRSA biofilm with reduction percentages of $63.82 \%$ and $59 \%$, respectively. As well as, other sub-MICs of polyphenol fraction of

Table 5. Anti-biofilm effect of Z. spina-christi total extract on S. aureus and MRSA biofilm

\begin{tabular}{|c|c|c|c|c|c|c|}
\hline \multirow{3}{*}{ Sub-MICs } & \multicolumn{3}{|c|}{ S. aureus } & \multicolumn{3}{|c|}{ MRSA } \\
\hline & \multicolumn{2}{|c|}{ Biofilm } & \multirow[b]{2}{*}{$\begin{array}{l}\text { Growth O.D. } \\
620 \mathrm{~nm}\end{array}$} & \multicolumn{2}{|c|}{ Biofilm } & \multirow[b]{2}{*}{$\begin{array}{l}\text { Growth O.D. } \\
620 \mathrm{~nm}\end{array}$} \\
\hline & $\begin{array}{l}\text { Formation } \\
\text { O.D. } 570 \mathrm{~nm}\end{array}$ & $\%$ reduction & & $\begin{array}{l}\text { Formation } \\
\text { O.D. } 570 \mathrm{~nm}\end{array}$ & $\%$ reduction & \\
\hline 0 & 1.288 & - & 1.2 & 0.982 & - & 1.3 \\
\hline $2 \mathrm{mg} / \mathrm{ml}$ & 0.281 & 78.18 & 1.1 & 0.163 & 81.9 & 1.1 \\
\hline $1 \mathrm{mg} / \mathrm{ml}$ & 0.834 & 35.24 & 1.2 & 0.597 & 39.2 & 1.2 \\
\hline $0.5 \mathrm{mg} / \mathrm{ml}$ & 1.071 & 16.84 & 1.1 & 0.865 & 11.9 & 1.3 \\
\hline $0.25 \mathrm{mg} / \mathrm{ml}$ & 1.287 & 0 & 1.3 & 0.982 & 0 & 1.2 \\
\hline
\end{tabular}

Table 6. Anti-biofilm effect of polyphenol fraction of Z. spina-christi on S. aureus and MRSA biofilm

\begin{tabular}{|c|c|c|c|c|c|c|}
\hline \multirow{3}{*}{ Sub-MICs } & \multicolumn{3}{|c|}{ S. aureus } & \multicolumn{3}{|c|}{ MRSA } \\
\hline & \multicolumn{2}{|c|}{ Biofilm } & \multirow[b]{2}{*}{$\begin{array}{l}\text { Growth O.D. } \\
620 \mathrm{~nm}\end{array}$} & \multicolumn{2}{|c|}{ Biofilm } & \multirow[b]{2}{*}{$\begin{array}{l}\text { Growth O.D. } \\
620 \mathrm{~nm}\end{array}$} \\
\hline & $\begin{array}{l}\text { Formation } \\
\text { O.D. } 570 \mathrm{~nm}\end{array}$ & $\%$ reduction & & $\begin{array}{l}\text { Formation } \\
\text { O.D. } 570 \mathrm{~nm}\end{array}$ & $\%$ reduction & \\
\hline 0 & 1.288 & - & 1.2 & 0.982 & - & 1.3 \\
\hline $200 \mu \mathrm{g} / \mathrm{ml}$ & 0.466 & 63.82 & 1.1 & 0.393 & 59.97 & 1.1 \\
\hline $100 \mu \mathrm{g} / \mathrm{ml}$ & 0.903 & 29.9 & 1.2 & 0.619 & 36.96 & 1.2 \\
\hline $50 \mu \mathrm{g} / \mathrm{ml}$ & 1.270 & 1.4 & 1.1 & 0.910 & 7.33 & 1.3 \\
\hline $25 \mu \mathrm{g} / \mathrm{ml}$ & 1.289 & 0 & 1.3 & 0.985 & 0 & 1.2 \\
\hline
\end{tabular}

Table 7. Anti-biofilm effect of Z. spina-christi total extract on $P$. aeruginosa biofilm

\begin{tabular}{llll}
\hline Sub-MICs & \multicolumn{3}{c}{$P$ aeruginosa } \\
\cline { 2 - 3 } & \multicolumn{2}{c}{ Biofilm } & Growth \\
& \multicolumn{2}{c}{ Formation \% reduction } & O.D. $620 \mathrm{~nm}$ \\
& O.D. $570 \mathrm{~nm}$ & \\
\hline 0 & 1.162 & - & 1.7 \\
$6 \mathrm{mg} / \mathrm{ml}$ & 0.006 & 99.48 & 1.64 \\
$3 \mathrm{mg} / \mathrm{ml}$ & 0.385 & 66.86 & 1.68 \\
$1.5 \mathrm{mg} / \mathrm{ml}$ & 0.971 & 16.43 & 1.70 \\
$0.750 \mathrm{mg} / \mathrm{ml}$ & 1.099 & 5.42 & 1.171 \\
\hline
\end{tabular}

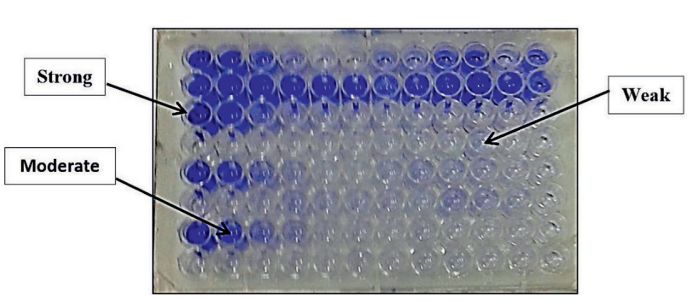

Fig. 7. Quantitative determination of biofilm formation by different MDR bacterial isolates using tissue culture plate method 


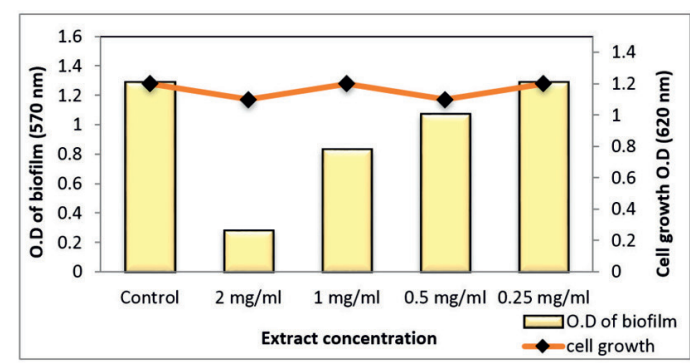

Fig. 8. Effect of sub-MIC of Z. spina-christi total extract on biofilm formation of MDR-S. aureus

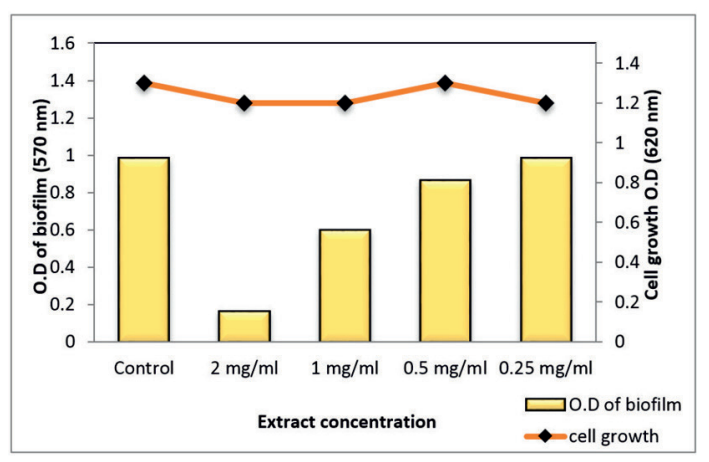

Fig. 9. Effect of sub-MICs of Z. spina-christi total extract on biofilm formation on MRSA strain

Z. spina-christi showed a weak biofilm eradication activity (Table 6 and Figs $10 \& 11$ ).

Total extract of $Z$. spina-christi at $1 / 2$ MIC exhibited a very strong biofilm eradication effect against $P$. aeruginosa biofilm, which is a key factor for the survival of this pathogen in various environments reached to $99.48 \%$ where it was close to a complete biofilm inhibition. In addition,

Table 8. Anti-biofilm effect of polyphenol fraction of $Z$. spina-christi on $P$. aeruginosa biofilm

\begin{tabular}{llll}
\hline Sub-MICs & \multicolumn{3}{c}{ P. aeruginosa } \\
\cline { 2 - 4 } & \multicolumn{2}{c}{ Biofilm } & Growth \\
& $\begin{array}{l}\text { Formation } \\
\text { O.D. } 570 \mathrm{~nm}\end{array}$ & \% reduction & O.D. $620 \mathrm{~nm}$ \\
& & & \\
\hline 0 & 1.162 & - & 1.7 \\
$600 \mu \mathrm{g} / \mathrm{ml}$ & 0.140 & 87.95 & 1.64 \\
$300 \mu \mathrm{g} / \mathrm{ml}$ & 0.488 & 58 & 1.68 \\
$150 \mu \mathrm{g} / \mathrm{ml}$ & 0.901 & 22.46 & 1.70 \\
$75 \mu \mathrm{g} / \mathrm{ml}$ & 1.163 & 0 & 1.171 \\
\end{tabular}

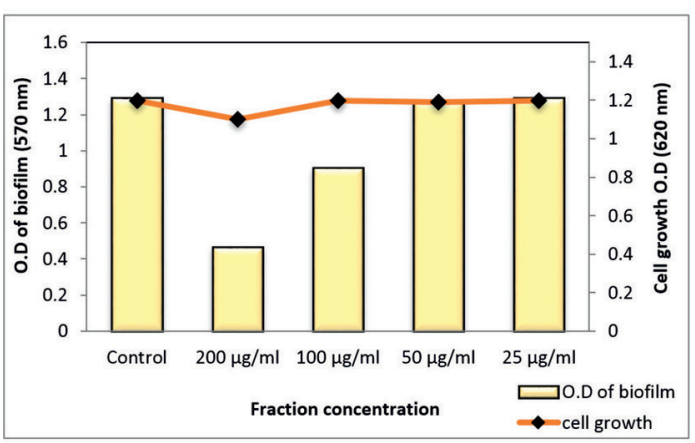

Fig. 10. Effect of sub-MICs of polyphenol fraction $Z$. spina-christi on biofilm formation of MDR-S. aureus

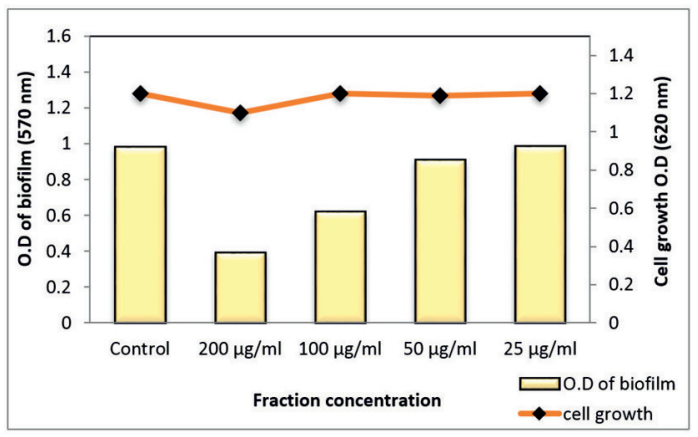

Fig. 11. Effect of sub-MICs of polyphenol fraction $Z$. spina-christi on biofilm formation of MRSA strain 3.6.2. against $P$. aeruginosa biofilm

$1 / 4$ MIC showed activity by $66.86 \%$ without affecting planktonic cell growth (Table 7 and Fig. 12). As well as, the polyphenol fraction at $1 / 2 \mathrm{MIC}$ showed a strong antibiofilm effect by $87.95 \%$ While, at $1 / 4$ MIC exhibited moderate eradication effect by $58 \%$ (Table 8 and Fig. 13). Other sub-MICs from the total extract and polyphenol fraction of Z. spina-christi showed a weak effect.

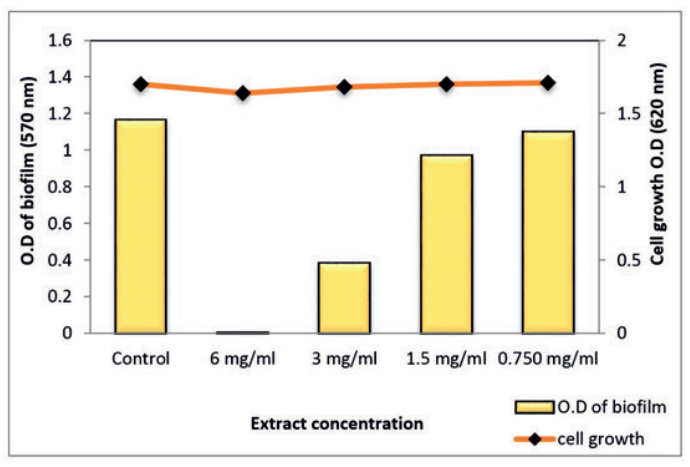

Fig. 12. Effect of sub-MIC of Z. spina-christi total extract on biofilm formation of MDR-P. aeruginosa 


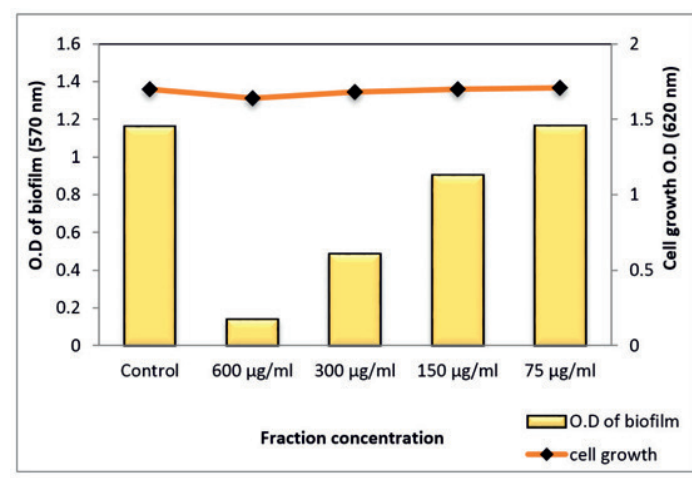

Fig. 13. Effect of sub-MICs of polyphenol fraction $Z$. spina-christi on biofilm formation of $P$. aeruginosa

\section{DISCUSSION}

This study has been aimed to investigate new antibacterial compounds of plants selected based on traditional medicinal use for growth and biofilm inhibitory activity targeting identified most multidrug-resistant bacteria isolated from clinical specimens. From all two hundred and fifty (250) bacterial isolates were isolated from the collected samples, only 29 isolates showed complete resistance to all tested antibiotics and represented about $11.6 \%$ of the total isolates. These MDR-strains were K. pneumoniae, E. coli, P. aeruginosa, S. aureus, and Methicillin-resistant- $S$. aureus (MRSA).

Antibiotic-resistant bacteria now are already widespread on the globe ${ }^{27}$. Excessive use of antibiotics has helped develop drug resistance in patients. In addition, the widespread use of antibiotics in the animal industry has also led to a significant selective pressure for antibioticresistant bacteria to develop ${ }^{28}$. The transfer of drug-resistant species from one country to another also increased with increasing patient movements and travel around the globe ${ }^{29}$. In addition, it was reported that ${ }^{30}$ most high level of multidrug resistance is reported in $S$. aureus, Methicillin-resistant S. aureus, K. pneumoniae, $A$. baumannii, E. coli, P. aeruginosa and Enterobacter spp, which cause the most of problems within the hospitals. It is interesting to find a bioactive compound of crude plant extracts, where modern antibiotic therapy has failed, with good activity against multidrug-resistant strains. In addition, novel anti-infectives that operate through different mechanisms of action are required ${ }^{5}$. Plants are a good source of natural products for the discovery of bioactive compounds ${ }^{6}$.

In addition, it has been shown the ability of phenolic compounds to exhibit a broad spectrum of antibacterial activity against Gramnegative and Gram-positive bacteria, including species of Escherichia, Salmonella, Staphylococcus, Streptococcus, Klebsiella, Proteus, Bacillus, and Clostridium $^{31}$. The primary mechanism involved in the antimicrobial effect was due to the inhibition of certain thiol-containing enzymes in the microorganisms by the rapid reaction of thiosulfinates with thiol groups ${ }^{32}$.

Moreover, for the presence of other active components like saponins, flavonoids, steroids, Glycosides, and Phlobatanins, which are known to have antimicrobial properties ${ }^{33,34}$. The current results also showed the moderate antibacterial effect of alkaloids portion of Z. spinachristi extract, and this could be due to its ability to interchelate with DNA of both Gram-positive and negative bacteria and interfere with cell division ${ }^{35}$. From the obtained results, it was found that the total extract of $Z$. spina-christi showed a strong antibiofilm effect against tested biofilms of $S$. aureus, $P$. aeruginosa, and MRSA strains. The antibiofilm effect of tested plant extract was supported by other studies which found that some plants could prevent the biofilm formation in some pathogens such as $P$. aeruginos $a^{36}$, S. pyogenes ${ }^{37}$, L. monocytogenes ${ }^{38}$, S. mutans ${ }^{39}$, and S. aureus ${ }^{40}$.

Many studies also in consistence with our results, concluded that the active constituents from the plants, such as luteolin ${ }^{41}$ and chrysin ${ }^{42}$ at subinhibitory concentrations showed an ability to inhibit the virulence factors of many bacteria, and fisetin reduced the antibiotic-resistant biofilm formation in S. aureus ${ }^{43}$. Therefore, the current findings have expanded the scope of previous results of many studies and demonstrated that the active compounds of medicinal plants differentially control several virulent activities of many bacteria.

\section{ACKNOWLEDGMENTS}

None.

\section{CONFLICT OF INTEREST}

The authors declare that there is no conflict of interest. 


\section{AUTHORS' CONTRIBUTIONS}

All authors listed have made a substantial, direct and intellectual contribution to the work, and approved it for publication.

\section{FUNDING}

None.

\section{DATA AVAILABILITY}

All datasets generated or analyzed during this study are included in the manuscript

\section{ETHICS STATEMENT}

Not applicable.

\section{REFERENCES}

1. Thabit, A.K.; Crandon, J.L.; Nicolau, D.P. Antimicrobial resistance: impact on clinical and economic outcomes and the need for new antimicrobials. Expert Opinion on Pharmacotherapy 2014, 16, 159-177., https://doi. org/10.1517/14656566.2015.993381

2. Founou, R.C.; Founou, L.L.; Essack, S.Y. Clinical and economic impact of antibiotic resistance in developing countries: A systematic review and meta-analysis. PLoS One 2017, 12, e0189621., https://doi.org/10.1371/ journal.pone.0189621

3. Yestrepsky, B.D.; Xu, Y.; Breen, M.E.; Li, X.; Rajeswaran, W.G.; Ryu, J.G.; Sorenson, R.J.; Tsume, Y.; Wilson, M.W.; Zhang, W., et al. Novel inhibitors of bacterial virulence: development of 5,6-dihydrobenzo[h] quinazolin-4(3H)-ones for the inhibition of group $A$ streptococcal streptokinase expression. Bioorg Med Chem 2013, 21, 1880-1897., https://doi.org/10.1016/j. bmc.2013.01.046

4. Escaich, S. Antivirulence as a new antibacterial approach for chemotherapy. Curr Opin Chem Biol 2008, 12, 400-408., https://doi.org/10.1016/j. cbpa.2008.06.022

5. Schroeder, M.; Brooks, B.D.; Brooks, A.E. The complex relationship between virulence and antibiotic resistance. Genes (Basel) 2017, 8, pii: E39., https:// doi.org/10.3390/genes8010039

6. Rossiter, S.E.; Fletcher, M.H.; Wuest, W.M. Natural products as platforms to overcome antibiotic resistance. Chem Rev 2017, 117, 12415-12474., https://doi.org/10.1021/acs.chemrev.7b00283

7. Wright, G.D. Opportunities for natural products in $21^{\text {st }}$ century antibiotic discovery. Nat Prod Rep 2017, 34, 694-701., https://doi.org/10.1039/C7NP00019G

8. Hoiby, N.; Bjarnsholt, T.; Givskov, M.; Molin, S.; Ciofu, O. Antibiotic resistance of bacterial biofilms. Int J Antimicrob Agents 2010, 35, 322-332., https://doi. org/10.1016/j.ijantimicag.2009.12.011

9. Lee, J.H.; Regmi, S.C.; Kim, J.A.; Cho, M.H.; Yun, H.; Lee, C.S.; Lee, J. Apple flavonoid phloretin inhibits Escherichia coli 0157:H7 biofilm formation and ameliorates colon inflammation in rats. Infect Immun 2011, 79, 4819-4827., https://doi.org/10.1128/
IAI.05580-11

10. Bauer, A.W.; Kirby, W.M.; Sherris, J.C.; Turck, M. Antibiotic susceptibility testing by a standardized single disk method. Am J Clin Pathol 1966, 45, 493-496. https://doi.org/10.1093/ajcp/45.4_ts.493

11. NCCLS/CLSI. Performance standards for antimicrobial susceptibility testing.; National Committee for Clinical Laboratory Standards / Clinical and Laboratory Standards Institute: Wayne, P. A., U. S. A, 2007; Vol. Seventeenth informational supplement.

12. Cheesbrough, M. District laboratory practice in tropical countries., 2nd ed.; Cambridge university press: New York., 2006. https://doi.org/10.1017/ CBO9780511543470

13. Collins, C.H.; Lyne, P.M. Microbiological methods., 8th ed.; Arnold: London., 2004.

14. Funke, G.; Funke-Kissling, P. Evaluation of the new VITEK 2 card for identification of clinically relevant gram-negative rods. Journal of Clinical Microbiology 2004, 42, 4067-4071., https://doi.org/10.1128/ JCM.42.9.4067-4071.2004

15. Funke, G.; Funke-Kissling, P. Performance of the new VITEK 2 GP card for identification of medically relevant gram-positive Cocci in a routine clinical laboratory. Journal of Clinical Microbiology 2005, 43, 84-88., https://doi.org/10.1128/JCM.43.1.84-88.2005

16. Faizi, S.; Khan, R.A.; Mughal, N.R.; Malik, M.S.; Sajjadi, K.E.; Ahmad, A. Antimicrobial activity of various parts of Polyalthia longifolia var. pendula: isolation of active principles from the leaves and the berries. Phytother Res 2008, 22, 907-912., https://doi.org/10.1002/ ptr.2414

17. Ekpo, M.A.; Etim, P.C. Antimicrobial activity of ethanolic and aqueous extracts of Sida acuta on microorganisms from skin infections. Journal of Medicinal Plants Research 3, 621-624.

18. Sofy, A.R.; Hmed, A.A.; Sharaf, A.M.A.; El-Dougdoug, K.A. Preventative and curative effect of Moringa oleifera aqueous extract to ensure safe natural antimicrobials targeting foodborne pathogens. Archives of Clinical Microbiology 2017, 8, 51.

19. Woo, W.S.; Chi, H.J.; Yun, H.S. Alkaloid screening of some Saudi Arabian plants. Saengyak Hakhoe Chi (Hanguk SaengyaK Hakhoe) 1977, 8, 109-113.

20. CLSI. Methods for dilution antimicrobial susceptibility tests for bacteria that grow aerobically; approved standard., 8th ed.; Clinical and Laboratory Standards Institute: Wayne, PA. M07-A8., 2009.

21. NARMS. National antimicrobial resistance monitoring system, enteric bacteria.; CDC: USA., 2002.

22. Andrews, J.M. Determination of minimum inhibitory concentrations. J Antimicrob Chemother 2001, 48 Supp/ 1, 5-16., https://doi.org/10.1093/jac/48. suppl_1.5

23. Sampaio, F.C.; Pereira, M.d.S.V.; Dias, C.S.; Costa, V.C.O.; Conde, N.C.O.; Buzalaf, M.A.R. In vitro antimicrobial activity of Caesalpinia ferrea Martius fruits against oral pathogens. Journal of Ethnopharmacology 2009, 124, 289-294., https://doi.org/10.1093/jac/48.suppl_1.5

24. Christensen, G.D.; Simpson, W.A.; Bisno, A.L.; Beachey, E.H. Adherence of slime-producing strains of Staphylococcus epidermidis to smooth surfaces. Infect 
Immun 1982, 37, 318-326. https://doi.org/10.1128/ IAl.37.1.318-326.1982

25. Stepanovic, S.; Vukovic, D.; Hola, V.; Bonaventura, G.D.; Djukic, S.; Clrkovic, I.; Ruzicka, F. Quantification of biofilm in microtiter plates: overview of testing conditions and practical recommendations for assessment of biofilm production by staphylococci. Apmis 2007, 115, 891 899., https://doi.org/10.1111/j.1600-0463.2007. apm_630.x

26. Chusri, S.; Sompetch, K.; Mukdee, S.; Jansrisewangwong, S.; Srichai, T.; Maneenoon, K.; Limsuwan, S.; Voravuthikunchai, S.P. Inhibition of Staphylococcus epidermidis biofilm formation by traditional Thai herbal recipes used for wound treatment. Evid Based Complement Alternat Med 2012, 2012, 159797., https://doi.org/10.1155/2012/159797

27. Golkar, Z.; Bagasra, O.; Pace, D.G. Bacteriophage therapy: a potential solution for the antibiotic resistance crisis. J Infect Dev Ctries 2014, 8, 129-136., https://doi.org/10.3855/jidc.3573

28. Ahmad, A.; Ghosh, A.; Schal, C.; Zurek, L. Insects in confined swine operations carry a large antibiotic resistant and potentially virulent enterococcal community. BMC Microbiol 2011, 11, 23, https://doi. org/10.1186/1471-2180-11-23

29. Richet, H.M.; Mohammed, J.; McDonald, L.C.; Jarvis, W.R. Building communication networks: international network for the study and prevention of emerging antimicrobial resistance. Emerg Infect Dis 2001, 7, 319-322., https://doi.org/10.3201/eid0702.010235

30. Pendleton, J.N.; Gorman, S.P.; Gilmore, B.F. Clinical relevance of the ESKAPE pathogens. Expert Rev Anti Infect Ther 2013, 11, 297-308., https://doi. org/10.1586/eri.13.12

31. Ankri, S.; Mirelman, D. Antimicrobial properties of allicin from garlic. Microbes Infect 1999, 1, 125-129., https://doi.org/10.1016/S1286-4579(99)80003-3

32. Rabinkov, A.; Miron, T.; Konstantinovski, L.; Wilchek, M.; Mirelman, D.; Weiner, L. The mode of action of allicin: trapping of radicals and interaction with thiol containing proteins. Biochim Biophys Acta 1998, 1379, 233-244.,https://doi.org/10.1016/S03044165(97)00104-9

33. Lee Chang, P. Who's in the business of saving lives?. J Med Philos 2006, 31, 465-482., https://doi. org/10.1080/03605310600912667

34. Lam, K.S. New aspects of natural products in drug discovery. Trends Microbiol 2007, 15, 279-289., https://doi.org/10.1016/j.tim.2007.04.001

35. Bukar, A.M.; Kyari, M.Z.; Gwaski, P.A.; Gudusu, M.; Kuburi, F.S.; Abadam, Y.I. Evaluation of phytochemical and potential antibacterial activity of Ziziphus spinachristi L. against some medically important pathogenic bacteria obtained from University of Maiduguri Teaching Hospital, Maiduguri, Borno State - Nigeria. Journal of Pharmacognosy and Phytochemistry 2015, 3, 98-101.

36. Adonizio, A.; Kong, K.F.; Mathee, K. Inhibition of quorum sensing-controlled virulence factor production in Pseudomonas aeruginosa by South Florida plant extracts. Antimicrob Agents Chemother 2008, 52, 198-203., https://doi.org/10.1128/AAC.00612-07

37. Limsuwan, S.; Voravuthikunchai, S.P. Boesenbergia pandurata (Roxb.) Schltr., Eleutherine americana Merr. and Rhodomyrtus tomentosa (Aiton) Hassk. as antibiofilm producing and antiquorum sensing in Streptococcus pyogenes. FEMS Immunol Med Microbio/ 2008, 53, 429-436., https://doi.org/10.1111/ j.1574-695X.2008.00445.x

38. Sandasi, M.; Leonard, C.M.; Viljoen, A.M. The effect of five common essential oil components on Listeria monocytogenes biofilms. Food Control 2008, 19, 1070-1075., https://doi.org/10.1016/j. foodcont.2007.11.006

39. Song, J.H.; Yang, T.C.; Chang, K.W.; Han, S.K.; Yi, H.K.; Jeon, J.G. In vitro effects of a fraction separated from Polygonum cuspidatum root on the viability, in suspension and biofilms, and biofilm formation of mutans streptococci. J Ethnopharmacol 2007, 112, 419-425., https://doi.org/10.1016/j.jep.2007.03.036

40. Nostro, A.; Sudano Roccaro, A.; Bisignano, G.; Marino, A.; Cannatelli, M.A.; Pizzimenti, F.C.; Cioni, P.L.; Procopio, F.; Blanco, A.R. Effects of oregano, carvacrol and thymol on Staphylococcus aureus and Staphylococcus epidermidis biofilms. J Med Microbiol 2007, 56, 519-523., https://doi.org/10.1099/ jmm.0.46804-0

41. Qiu, J.; Li, H.; Meng, H.; Hu, C.; Li, J.; Luo, M.; Dong, J.; Wang, X.; Wang, J.; Deng, Y., et al. Impact of luteolin on the production of alpha-toxin by Staphylococcus aureus. Lett App/ Microbiol 2011, 53, 238-243., https:// doi.org/10.1111/j.1472-765X.2011.03098.X

42. Wang, J.; Qiu, J.; Dong, J.; Li, H.; Luo, M.; Dai, X.; Zhang, Y.; Leng, B.; Niu, X.; Zhao, S., et al. Chrysin protects mice from Staphylococcus aureus pneumonia. J Appl Microbiol 2011, 111, 1551-1558., https://doi. org/10.1111/j.1365-2672.2011.05170.x

43. Durig, A.; Kouskoumvekaki, I.; Vejborg, R.M.; Klemm, P. Chemoinformatics-assisted development of new anti-biofilm compounds. Appl Microbiol Biotechnol 2010, 87, 309-317., https://doi.org/10.1007/s00253010-2471-0 